\title{
MEASURING FARMLAND LOSS: LESSONS FROM ONTARIO, CANADA
}

\author{
SARA EPP \& WAYNE CALDWELL \\ University of Guelph, Canada
}

\begin{abstract}
Farmland in Ontario, Canada is under immense pressure from development associated with population growth and urbanization. The future sustainability of agriculture in Ontario is dependent upon a stable land base and precise understanding of the availability of farmland; however, in many communities, farmland is sacrificed for residential subdivisions, commercial developments and aggregate operations, among others. The provincial government has recognized the development threats facing farmland and created the Greenbelt Act (2005) to protect prime farmland and other sensitive landscapes. While this protectionist policy has appeared to stop some development, farmland continues to be lost to non-farm land uses and a policy failure is assumed. In reality, much of this land was designated decades prior for urban development but the loss is not evident until urban development begins. In order to assess the strength of the Greenbelt policy and understand the amount of farmland lost, quantitative data at a region or county level is needed. Currently, no accurate data regarding the amount of farmland lost to other land uses exists. This presentation will explore a new methodology for measuring the loss of farmland through official plan amendments on private property in southern Ontario. Analysis of data in the form of a case study is presented from 2 counties and regions. This highlights the amount of farmland converted to other land uses both before and after Greenbelt Act (2005) came into force. The economic and environmental impacts of farmland loss and the role of planning policies will also be discussed. This analysis and methodology will be applicable in many different jurisdictions.
\end{abstract}

Keywords: agriculture, farmland, urban sprawl, development, land use planning, Greenbelt.

\section{INTRODUCTION}

A stable farmland base is necessary for a viable and sustainable agricultural industry. Throughout North America, population growth and resulting development pressures result in sprawling development that consume agricultural land. Research regarding urban encroachment on rural landscapes is, for example, evident in Canada [1], [2], the United States [3], [4] and Europe [5]. Urban sprawl, defined as the outward, uncontrolled growth of cities [6], is largely recognized as an outcome of poor planning policies, which negatively impacts the environment, human health and agricultural capacity. Farmland serves many functions beyond the production of food and fibre, including environmental services, such as wildlife habitat and the continued conversion of these lands to non-farm land uses is concerning.

The development impacts on agricultural systems is problematic, as the agricultural land base is eroded, resulting in a disjointed countryside that lacks a stable supply of farmland. Remaining agricultural areas are further impacted by urban sprawl, as city boundaries infringe upon established agricultural networks [7]. The result of residential development in close proximity to active agricultural land often results in conflicts related to the appropriateness of agricultural activities, further impacting the viability of agriculture [7].

The linkages between farmland loss and urban development are well understood. Agricultural areas located within the urban-rural fringe are under the greatest threat of development, given urban growth pressures. The loss of farmland to urban growth is not limited to developed nations, however the intensity of loss increases significantly in less developed nations with high levels of economic growth [8]. Within Canada, 15,200 square 
kilometres of agricultural land has been consumed by urban land uses between 1971 and 2001 [9] and to date, the rapid expansion of urban communities has further exacerbated the issue. In recognition of the loss of agricultural land, strict planning policies that protect agricultural land from development have been created. Examples of such policies include British Columbia's Agricultural Land Reserve and Ontario's Greenbelt, which prohibit development of farmland within provincially designated areas. While Ontario's Greenbelt has resulted in the protection of more than two million acres of farmland and other sensitive landscapes, farms outside this area continue to be converted to non-farm land uses. While urban development of farmland outside of the protected countryside continues, what is most challenging is the lack of data that accurately documents this conversion.

In this paper, we present a new method for measuring the amount of farmland converted to non-farm land uses at the time the planning decision was made. This method, we argue, is more predictive and presents accurate and timely data regarding farmland loss, which is necessary for evaluating the success of provincial planning policies and understanding the impacts of population growth on farmland availability. We begin with a review of the study area, including population growth, development pressures and planning legislation within the province of Ontario. Following this, we provide a detailed analysis of our method for measuring farmland loss and present two case studies demonstrated the application of this method in southern Ontario: Wellington County and York Region. We conclude with a discussion on the implications of this data and the effectiveness of land use planning policies in Ontario.

\section{STUDY AREA}

\subsection{Location}

This study focused on southern Ontario and more specifically, a region known as the Greater Golden Horseshoe (GGH). The GGH, as depicted in Fig. 1, is comprised of 15 counties and regions that surround the Greater Toronto Area, Canada's largest urban area. This geographic region is nearly 32,000 square kilometres in size and is the most rapidly urbanizing area within the country. In 2016, this area included a population of more than 9 million people [10]. It is anticipated that by 2041, the GGH will have a population of 13.5 million people, resulting in a growth rate of more than $30 \%$. Much of this growth is attributed to immigration and the GGH is uniquely multicultural, with a highly educated workforce. The GGH also represents a significant economic region, responsible for $25 \%$ of Canada's gross domestic product. While this is an economically diverse region, a driving feature of this area is its location within the Great Lakes system and proximity to the United States [11].

With rapid population growth anticipated and urban development expected to increase, it is important to recognize that the GGH contains many significant ecological and hydrological features, as well as some of Canada's best quality farmland [11]. In Canada, farmland has been classified according to production potential through the Canada Land Inventory (CLI). The CLI has seven distinct classes of soil, with Classes 1-3 considered prime agricultural land, representing the highest capability for agriculture. By way of contrast, Class 5 and 6 soils have significant limitations for agriculture, while Class 7 soils have no agricultural capability. Across Canada, only 5\% of the country's land mass is comprised of prime agricultural land. Class 1 soils, considered free of limitations for crop production, account for less than $1 \%$, with the majority of Class 1 soils located in Ontario. 


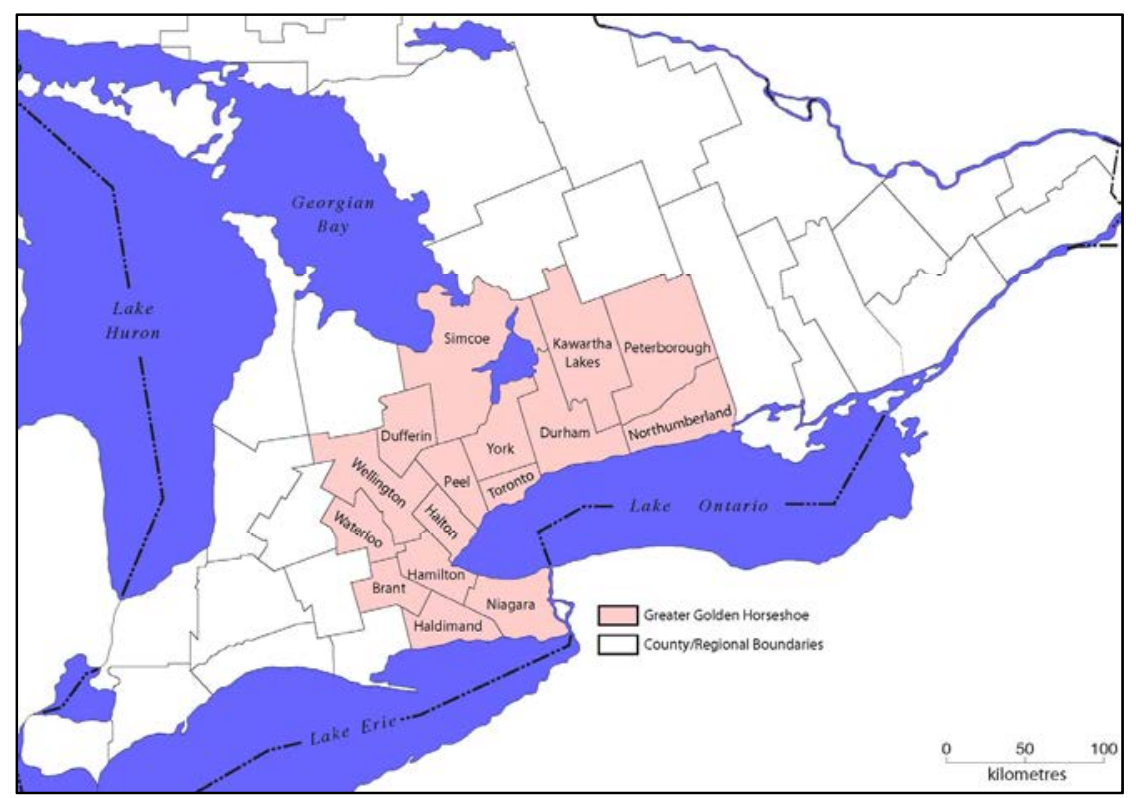

Figure 1: Location of the Greater Golden Horseshoe. (Source: modified from Brock University map, data and GIS library [14].)

Moreover, research has been completed that demonstrates significant increases in productivity with increasing soil capability (i.e. the best quality soils are much more productive than lower capability soils) [12], [13]. It is important to note that much of this prime agricultural land is in close proximity to the GTA and is under constant threat of development.

\subsection{Farmland loss and planning policies}

The loss of prime agricultural land to development is a significant concern across the country, however, the federal government has a minimal role, as land use planning powers are considered provincial domain. The government of Ontario has recognized the significant loss of prime agricultural land in the province and the development pressure much of the remaining land is under. In recent years, there have been several policies and land use plans put into place by the provincial government that work to protect prime agricultural land from development. The most important of these policies being the Provincial Policy Statement and Greenbelt Plan.

\subsubsection{Provincial policy statement}

The Provincial Policy Statement (PPS) outlines the province's policies on land use planning. The PPS 2005 applies across the entire province. The 2005 version of the PPS directs that "prime agricultural areas" shall be protected for long-term use in agriculture. In supplement to this, the PPS identified that removal of lands from prime agricultural areas would only be permitted for expansions of settlement areas, mineral and petroleum resource extraction and limited non-residential uses provided there are no reasonable alternatives. In 2014, the PPS 
was updated and provided further guidelines for identifying, designating and protecting prime agricultural lands at the municipal level [15].

\subsubsection{Greenbelt Plan}

The Greenbelt Plan, created in 2005 and updated in 2016, protects some Prime Agricultural Land in the Greater Golden Horseshoe from urban development. Policies within the Greenbelt Plan protect prime agricultural land by identifying those lands as areas where development should not occur, preventing loss and discouraging fragmentation. Specifically, the Greenbelt Plan outlines that within the "Protected Countryside" municipalities are not permitted to redesignate specialty crop areas and prime agricultural lands for non-farm land uses. As depicted in Fig. 2, the Greenbelt Area comprises more than two million acres of farmland and other sensitive ecological landscapes within southern Ontario. The land protected by the Greenbelt Plan represent some of the province's best agricultural land. Much of this land is within close proximity of the GTA and prior to the creation of the Greenbelt Plan, was under constant threat of development due to urban growth pressures.

\subsubsection{Local planning policies}

The province has given municipalities power to create their own land use planning policies, as long as these policies are in conformity with provincial legislation and provincial interests. Of particular importance are Official Plans, which are created at the municipal or county/regional level. Official Plans serve as a guiding document that outline the vision of the community and designate landscapes for a variety of land uses. Any community with lands protected by the Greenbelt Plan would be required to identify such areas as protected countryside within their official plan. Agricultural lands outside of the Greenbelt Plan would be designated as agricultural but land use protections would vary. Of importance is the understanding that prime agricultural lands not protected by provincial policy could be redesignated to non-farm land uses through amendments to local official plans. The agricultural areas protected by the Greenbelt Plan are not inclusive of all prime agricultural land within the province, nor does the Greenbelt Plan or any other provincial policy prevent municipalities from redesignating unprotected prime agricultural land to non-farm land uses.

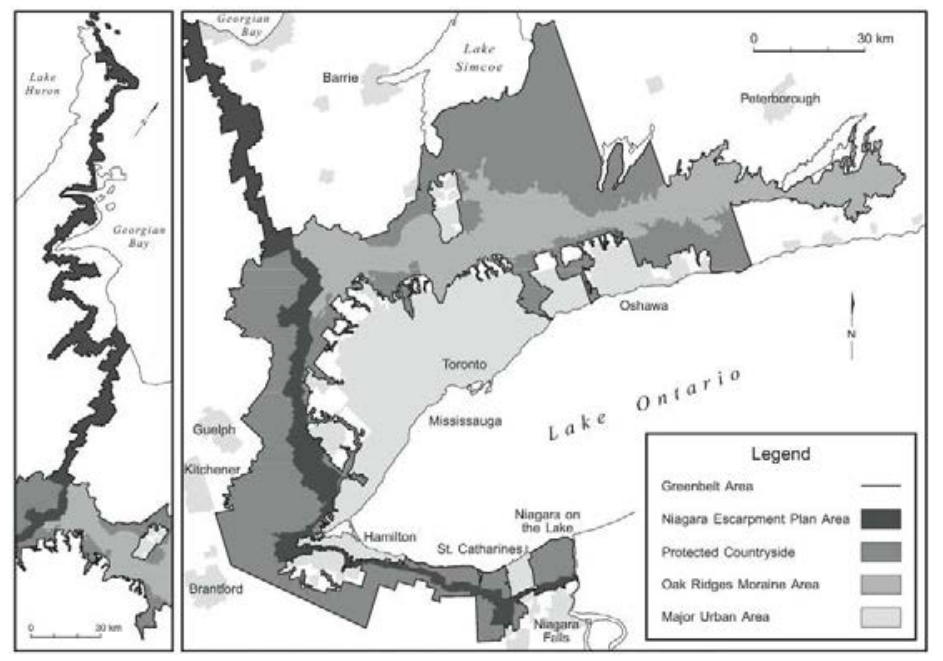

Figure 2: Map of Greenbelt area. 


\section{METHOD}

As the population in southern Ontario is expected to grow, urban development will also increase. Farmland within the GGH, already under development pressure, is at a greater risk of being developed for non-farm land uses. Currently, accurate data regarding the amount of farmland converted to non-farm land uses is not available. The only tool available that documents changes to farmland use is the Census of Agriculture. The Census of Agriculture provides a broad range of data regarding agricultural land in production every five years and is administered by the federal government of Canada. While the Census of Agriculture provides detailed statistics regarding the amount of land currently in production, it does not provide any qualitative data regarding changes between Census results. For example, the area farmed in Wellington County decreased by nearly 7\% between 2011 and 2016 but there is no indication of what factors contributed to this decline. As such, we can only make one of two assumptions about the status of those farms: the farm was redeveloped for non-farm land uses or the farmland still exists but is fallow.

\subsection{Limitations with existing methods}

In Ontario, when the land use designation for a farm is changed to a non-farm land use, the physical change in terms of the actual construction of new development may not occur for decades. As the Census of Agriculture only documents land that is currently in production, productive farmland that is designated through an official plan with a non-farm land use would continue to be included until the farm is developed. Once the farm activity ceases, the farm would not be counted within the Census of Agriculture and a decline in productive farmland would occur. From a planning perspective, this data is insufficient and not reflective of actual land use planning decisions. In most communities, residents may be unaware that a change in land use designation occurred until the bulldozer hits the ground. As depicted in Fig. 3, for many residents, a development sign is the most significant indication that land that was once a farm will soon be developed.

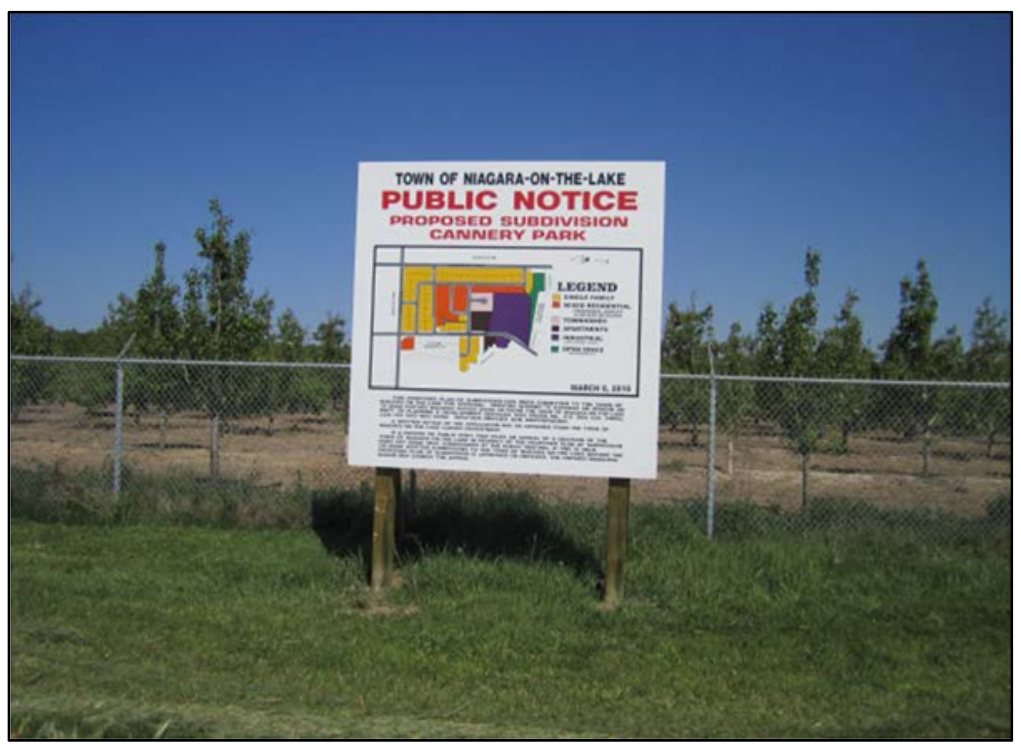

Figure 3: A change in designation is often realized only when the bulldozer hits the ground. 
The farm was actually redesignated to an urban land uses 40 years earlier but remained an active farm and neighbouring residents were likely unaware of the planning decision made decades earlier. It is interesting to note that this farm would have been captured in the Census of Agriculture as a productive farm since the time of the planning decision, as land use designation changes do not impact the use of land until construction actually begins.

When farms, such as the farm in Fig. 3, become actively developed, a policy failure is often assumed. For communities included within the Greenbelt Plan, for example, many criticize the plan as ineffective. In reality, the Greenbelt Plan cannot protect farms that were already designated for an urban use. Given the significant delays between land use decisions and the actual development, it could be argued that if a policy failure occurred, it was decades earlier when the initial planning decision was made.

\subsection{New method for measuring farmland loss}

The delays between planning approvals and development and limitations of data captured in the Census of Agriculture help demonstrate the need for accurate and timely data regarding farmland loss. This study created a new method for measuring the loss of prime agricultural land through planning decisions made at a local level. Specifically, official plan amendments that redesignated prime agricultural land to a non-farm land uses between 2000-2015 were tracked. Official plans are adopted by municipalities and provide the framework for land use planning decisions. It is our argument that a farm is actually lost to development when the planning decision is made, regardless of when the farm operation ceases. The timeframe for this study is significant as it captures farmland conversions both before and after the Greenbelt Plan came into force. This allowed us to assess the strength of the Greenbelt Plan and determine if any farmland within the protected countryside was converted after the policy came into effect. In the section that follows, we provide a case study analysis of two sites within our study area and compare the amount of farmland converted, the nature of the planning decisions and the effectiveness of local planning policies.

\section{CASE STUDY}

The following two case studies demonstrate the value of capturing the amount of prime agricultural land converted to non-farm land uses through official plan amendments. This data is both accurate and timely, as it is tabulated by year of approval. The data was captured in three categories:

1. Prime agricultural land redesignated to a development designation (including but not limited to urban, residential, commercial, industrial and recreational designations);

2. Prime agricultural land redesignation to a rural designation; or

3. Prime agricultural land that retained its designation but was given site specific amendments to allow non-farm land use.

The redesignation of prime agricultural land to a rural designation was captured separately from development, as it still permitted agriculture to occur. Rural designations varied by county and region but generally granted a broader range of land use activities than a prime agricultural designation. Often, these redesignations were for institutional uses, such as schools and churches. Site specific amendments were also captured separately as they maintained the prime agricultural designation but permitted a variety of non-farm land uses, such as recreation. Such amendments are unique, as the designation is not altered but the permitted uses are; these amendments contributed to the loss of prime agricultural land. 


\subsection{Wellington County}

Wellington County is a predominantly rural region with a population of approximately 220,000 people and a land area of 266,000 hectares. This results in a relatively low population density of 0.8 people/hectare. Over the course of the study period, the average rate of population growth was $5.5 \%$, modestly higher than the provincial average of $5.15 \%$. More than half of the county was classified as active farmland in the 2016 Census of Agriculture, totalling nearly 190,000 hectares of land, a decrease of 7\% from the 2011 census. Agriculture is a valuable industry within the county, with gross farm receipts valued at $\$ 943.2$ million or $\$ 4,997$ per hectare. While agriculture in Wellington County is diverse, dairy, calves and cattle and poultry represent $60 \%$ of farm cash receipts. Wellington County is within commuting distance of the GTA and given the relatively lower cost of housing in the County, is facing some urban growth and development pressure.

\subsubsection{Planning policies}

Wellington County's Official Plan includes a Rural System with land use designations for Prime Agricultural Areas, Secondary Agriculture Areas, Recreational Areas, Rural Employment and Country Residential Areas. Prime Agricultural Areas are defined as Class 1, 2 and 3 agricultural soils, associated 4 to 7 soils and additional areas where there is a local concentration of farms which exhibit the characteristics of ongoing agriculture. Secondary Agriculture Areas are non-prime farmland but which can sustain certain agricultural activities. Agriculture remains a promoted use in the Secondary Agriculture Area, however additional uses are permitted. All official plan amendments that redesignated farmland were documented but only those amendments that redesignated prime agricultural land were captured in this study.

\subsubsection{Trends in agricultural conversion}

Over the course of the study period, 27 official plan amendments related to prime agricultural land were documented and are listed in Table 1. Since the creation of the Greenbelt Plan, no amendments in Wellington County occurred on lands protected under this Plan, therefore demonstrating the strength of this provincial policy. Of the 27 amendments approved, 23 pertained to the redesignation of Prime Agricultural Areas to a development designation, totalling 812 hectares of land. "Urban area expansions" comprised 11 of these amendments, while the remainder were redesignations for hamlets, industrial, institutional or recreational uses in the countryside.

Wellington County is unique in that it did not use a rural designation for the conversion of Prime Agricultural Areas. As such, no official plan amendments were captured under a rural designation. The study did, however, capture the conversion of Prime Agricultural Area to Secondary Agriculture Area. Over the course of the study period, three amendments redesignated Prime Agricultural Area to Secondary Agricultural Area. Two of these amendments were the result of a land evaluation and area review study which identified areas unsuitable for the Prime Agricultural Area designation. While these two OPAs totalled 16,263 hectares of land, according to the Canada Land Inventory, this land was not considered prime agricultural land. As such, these two amendments have been qualified as housekeeping amendments and have not been included in this study. The third OPA redesignated 32 hectares of Prime Agricultural Area to the Secondary Agricultural Area for the purpose of severing the property. This OPA is also considered a housekeeping amendment as a secondary designation is more appropriate, given the lower capability soils. 
Table 1: Data regarding the conversion of prime agricultural land in Wellington County, 2000-2014.

\begin{tabular}{|l|l|}
\hline $\begin{array}{l}\text { Prime agricultural area redesignated to a development designation (e.g. } \\
\text { urban, residential and employment) }\end{array}$ & 817 ha \\
\hline Prime agricultural area redesignated to a rural designation & 0 ha \\
\hline $\begin{array}{l}\text { Prime agricultural area with a site-specific amendment to allow additional } \\
\text { non-farm land uses }\end{array}$ & 86 ha \\
\hline Total amount of prime agricultural area converted & 903 ha \\
\hline Total number of amendments & 27 \\
\hline $\begin{array}{l}\text { Amount of prime agricultural area within the Greenbelt Plan area } \\
\text { converted to non-farm land uses }\end{array}$ & 0 ha \\
\hline
\end{tabular}

The last redesignation category captured the site-specific amendments to prime agricultural land that did not alter the agricultural designation. In Wellington County sitespecific policy amendments occurred four times and allowed additional uses within the Prime Agricultural Area. These uses totalled 86 hectares and included a landscape materials sales yard, private residences, a golf course, and a flour mill/grain elevator combination.

\subsection{York Region}

Unlike Wellington County, York Region can be characterized as predominantly urban, with some rural areas. York Region has a population of approximately 1.1 million people and a land area of 176,000 hectares, resulting in a population density of 6.3 people/hectare. The average rate of population growth during the study period was $11.6 \%$, more than double the provincial average. According to the 2016 Census of Agriculture, 57,700 hectares of land are active farms, a decrease of 19\% from the 2011 Census. The value of agriculture is significantly lower in York Region, with gross farm receipts worth $\$ 301.5$ million but per hectare, is slightly higher than Wellington County, at $\$ 5,224$. The higher per hectare farm receipts can be attributed to the type of agriculture in the region, with fruits and vegetables and floriculture and nurseries representing $40 \%$ and $16 \%$, respectively. York Region is adjacent to the GTA and has significant urban growth pressure. While a large proportion of the region is protected by the Greenbelt Plan, the remaining unprotected prime agricultural land is under threat of development.

\subsubsection{Planning policies}

In York Region, agricultural activity is permitted in three designations: The Holland Marsh Specialty Crop Area, Agricultural Areas and Rural Areas. Within the Greenbelt Plan, the Holland Marsh is designated as a Specialty Crop Area for its black organic and muck soils suitable for a range of horticultural crops and receives the highest level of protection for future agricultural use through the Provincial Policy Statement. Both lands designated as Agricultural Areas or the Holland Marsh Specialty Crop Area permit a range of farm practices. Rural Areas support agriculture as a primary use but also permit uses such as equestrian facilities, farm markets, rural settlements, existing rural residential and estate residential development and golf courses. Lastly, Agricultural Policy Areas, as identified in York's Regional Greenlands System, were included in this study. 
Table 2: Data regarding the conversion of prime agricultural land in York Region, 2000-2014.

\begin{tabular}{|l|l|}
\hline $\begin{array}{l}\text { Prime agricultural area redesignated to a development designation (e.g. } \\
\text { urban, residential and employment) }\end{array}$ & 5,233 ha \\
\hline Prime agricultural area redesignated to a rural designation & 1,755 ha \\
\hline $\begin{array}{l}\text { Prime agricultural area with a site-specific amendment to allow additional } \\
\text { non-farm land uses }\end{array}$ & 0 ha \\
\hline Total amount of prime agricultural area converted & 6,988 ha \\
\hline Total number of amendments & 16 \\
\hline $\begin{array}{l}\text { Amount of prime agricultural area within the Greenbelt Plan area } \\
\text { converted to non-farm land uses }\end{array}$ & 0 ha \\
\hline
\end{tabular}

\subsubsection{Trends in agricultural conversion}

Over the course of the study, 16 official plan amendments related to the conversion of prime agricultural land were documented and summarized in Table 3. A total of 11 amendments pertained to the conversion of prime agricultural land to a development designation. These designations totalled 5,233 hectares of land. With rapid population growth anticipated, urban development is expected to increase due to growth pressures.

The remaining five amendments redesignated Agricultural Areas to Rural Areas for nonagricultural land uses. These uses included a fuel station, storage facility, cemetery and residential subdivision.

During the study period, there were two amendments passed in the Greenbelt area: both applications were initiated prior to the December 16, 2004 implementation date of the plan. Amendments to redesignate Prime Agricultural Areas in York Region continued in the areas outside the Protected Countryside after the implementation of the Greenbelt. It is important to note that after the creation of the Greenbelt Plan, no amendments were permitted in the protected countryside, further demonstrating the strength of provincial policy.

\section{CONCLUSION}

Agricultural land is a precious commodity. Prime agricultural land even more so. Agriculture in Canada, like much of the rest of the world is dependent on an available, productive, and yet limited land base. While Canada is a huge country the total amount of land available for production, as a percentage of the total land area is relatively small. Moreover, it is not a coincidence that the very best land with the greatest potential for agriculture lies in the path of many of our largest cities.

This paper details the results of a new method for measuring farmland loss. This method tracks the approval of municipal planning decisions in a way that foretells the actual conversion of farmland into other uses. The paper demonstrates that this method can be helpful in evaluating the effectiveness of policy in real time, in contrast to waiting for census results that document the conversion of farmland after it has already happened. From these revised methods we can offer the following general conclusions:

- Within Ontario the Greenbelt established around the City of Toronto and associated urban centers has been remarkably effective in curtailing development within the area known as the Protected Countryside.

- Within Ontario we have been able to document that some regional and county jurisdictions have a better track record in encouraging the protection of farmland and the intensification of urban settlements. 
- This method of measuring farmland loss has potential applicability around the world. In many countries land use decisions rest primarily with municipal governments. Measuring approvals at this level can help to describe large regional trends, successes and failures in helping to guide growth.

- This method brings focus to the importance of prime land. While there may be other lands with capacity for agricultural production, prime lands are the most productive. This can help to ensure a profitable agricultural sector and help to encourage the production of food with the smallest ecological footprint. This has corresponding benefits for society as a whole

\section{ACKNOWLEDGEMENT}

The authors would like to acknowledge the funding assistance provided by the Ontario Ministry of Agriculture, Food and Rural Affairs through the Partnership Agreement with the University of Guelph.

\section{REFERENCES}

[1] Troughton, M., Canadian farmland, a fluctuating commodity Farmland Preservation, eds W. Caldwell, S. Hilts \& B. Wilton, University of Manitoba Press: Winnipeg, Manitoba, pp. 13-27, 2017.

[2] Wilton, B., Farmland preservation perspectives. Farmland Preservation, eds W. Caldwell, S. Hilts \& B. Wilton, University of Manitoba Press: Winnipeg, Manitoba, pp. 1-12, 2017.

[3] Daniels, T., Farmland preservation policies in the United States. Farmland Preservation, eds W. Caldwell, S. Hilts \& B. Wilton, University of Manitoba Press: Winnipeg, Manitoba, pp. 184-199, 2017.

[4] Daniels, T. \& Bowers, D., Holding Our Ground: Protecting America's Farms and Farmland, Island Press: Washington, DC, 1997.

[5] Skog, K.L. \& Steinnes, M., How do centrality, population growth and urban sprawl impact farmland conversion in Norway? Land Use Policy, 59, pp. 185-196, 2016.

[6] Patel, P., Cities without sprawl: A utopian concept. International Journal of Research, 1(5), pp. 669-679, 2014.

[7] Daniels, T., When City and Country Collide - Managing Growth in the Metropolitan Fringe, Island Press: Washington, DC, 1998.

[8] Azadi, H., Ho, P. \& Hasfiati, L., Agricultural land conversion drivers: A comparison between less developed, developing and developed countries. Land Degradation \& Development, 22(6), pp. 596-604, 2011.

[9] Connell, D.J. et al., Food sovereignty and agricultural land use planning: The need to integrate public priorities across jurisdictions. Journal of Agriculture, Food Systems, and Community Development, 3(4), pp. 117-124, 2013.

[10] Ministry of Finance, Ontario Population Projections Update, 2016-2041, Queen's Printer for Ontario: Toronto, 2017.

[11] Ministry of Municipal Affairs, Growth Plan for the Greater Golden Horseshoe, Queen's Printer for Ontario, Toronto, 2017.

[12] Hoffman, D.W., The Assessment of Soil Productivity for Agriculture, Ministry of Agriculture and Food ARDA Report 4: Toronto, 1971.

[13] Hoffman, D.W., Crop yields of soil capability classes and their uses in planning for agriculture. PhD dissertation, University of Waterloo, 1973. 
[14] Brock University, Map, Data \& GIS Library, Southern Ontario - Regions Map, https://brocku.ca/library/collections/mdg/maps-geodata/outline-maps/. Accessed on: 10 Feb. 2017.

[15] Ministry of Municipal Affairs, Provincial Policy Statement, Queen's Printer for Ontario, Toronto, 2015. 